\title{
Relationship between Social Capital and Technology Transfer Performance: A Study on Companies in Technology Park
}

\author{
Rahimi Abidin, Norlena Hasnan, Che Sobry Abdullah, Shahimi Mohtar \\ and Faisal Zulhumadi
}

Universiti Utara Malaysia, Sintok, Kedah, Malaysia

Correspondence should be addressed to: Rahimi Abidin; a.rahimi@uum.edu.my

Received 31 August 2012; Accepted 17 June 2013; Published 23 October 2013

Academic Editor: Ali Saleh Ahmed Alarussi

Copyright (C) 2013 Rahimi Abidin, Norlena Hasnan, Che Sobry Abdullah, Shahimi Mohtar and Faisal Zulhumadi. Distributed under Creative Commons CC-BY 3.0

\begin{abstract}
Tacit knowledge and personal experience of an individual can only be obtained in a tacit manner. Social capital is a prominent concept that provides a foundation to describe and characterize the properties. Therefore social interaction is very important to facilitate technological knowledge transfer among the units within an organisation. This paper aims to contribute to the existing knowledge in the field of technology transfer by exploring the concept of social capital. It discusses the technology transfer performance and focuses on the important firm-specific asset, which is social capital. By using the data from a survey on industrial firms in one of the technology parks in Malaysia, this paper provides an investigation on the relationship between social capital and technology transfer performance, within the technology park incubating company setting. It was found that social capital has significant relationships with the performance of technology transfer.
\end{abstract}

Keywords: Technology transfer; social capital; high technology firms, Technology Park.

\section{Introduction}

Technology is an expression of human creativity and it depends on harnessing information into knowledge and applying this knowledge to the betterment of human conditions (Li-Hua and Khalil, 2006). It is a combination of "hardware" (buildings, plant and equipment), "software" (the way to operate the hardware), and "know-how" (skills, knowledge, and experience together with suitable organizational and institutional arrangement). It was highlighted in their study that in order to understand the concept of technology, four inter-linked elements should be considered, namely technique, knowledge (normally being considered as "technology" upon its application), the organization of the production, and the product (Li-Hua \& Khalil, 2006). They also noted that knowledge is the key to control technology as a whole. When the technological product is transferred, the knowledge of its composition, use, and application are also transferred. This approach shows that technology and knowledge transfer are not separable. 
Technology transfer is an alternative way to improve and adopt technologies from others. The technology to be transferred can include intangible assets which do not have specific form that has economic value, for example in a narrow sense it can be manufacturing site, manufacturing method, confidential skill, and know how, or in the wider sense it means the entire intellectual property (Noor, 2010). Technology transfer is not a new concept; and research in technology transfer has been conducted from various perspectives. The mainstream of the existing literature on technology transfer is concerned solely with inter-firm diffusion while intra-firm diffusion has been largely ignored, although it is considered important (Battisti \& Stoneman, 2005). This paper contributes to the existing knowledge in the field of technology transfer by exploring the concept of social capital. It discusses the technology transfer performance and focuses on the important firm-specific asset, which is social capital.

\section{Technology Transfer Performance}

Transferring technology is more complicated and specialized than transferring of general goods, and there are greater possibilities to enhance professional services and business opportunities. Technology transfer expresses different meanings to different people and different organizations (Li-Hua, 2006). Conventionally, technology transfer was conceptualized as the transfer of hardware objects, but in the present day it often involves information (e.g., a computer software program or a new idea) that may be completely devoid of any hardware aspects.

Technology transfer encompasses the movement of physical structure, knowledge, skills, organization, values, and capital from the site of generation to the receiving site (Mitelman and Pasha, 1997). A firm's ability to achieve its goal or objective is an indication of technology transfer performance and success (Jian and Li-Hua, 2006). According to Rose et al., (2009), technology transfer success includes the ability to learn, acquire, absorb and apply new external technologies and knowledge embedded in product materials, physical assets, processes and production, and management capabilities and not limited to possessing the ability to operate, maintain or repair the machineries in the production level. Three common objectives that firms hope to achieve through technology transfer are the introduction of new techniques, the improvement of new techniques and the generation of new knowledge (Li-Hua, 2006).

The unseen aspects of technology, such as knowledge, skills, and organisation, might be much more critical than the physical aspects for the successful transfer of technology (Battisti \& Stoneman, 2005; Choi, 2009). Soft technology has been studied in diverse disciplines such as science, economic, sociology, anthropology, and management (Tze et al., 2011). Numerous studies, for example Foss and Pedersen (2002), Noor (2010), and Sarif and Ismail (2006), had looked at the soft technology transfer. These transfer processes have otherwise been labeled as intra-unit knowledge sharing or subsidiary inflow or outflow (Tze et al., 2011; Gupta \& Govindarajan, 2000).

Researchers have investigated different variables in attempting to explain the phenomenon of technology transfer. Szulanski et al., (2004) used "accuracy of reproduction" as their dependent variable. Alternatively, Ambos and Schlegelmilch (2008) measured R\&D performance directly at each international unit in obtaining number of patents per annum. While the measures mentioned above focus on the results of soft technology transfer, others have looked at the process, for example, for the lack of the better name, "tacitness" and "knowledge ambiguity" has been dubbed as difficulty of transfer. The most widely used term is Von Hippel's (1994) metaphor of "stickiness" (Jensen et al., 2005; Riusala \& Smale, 2007). On the individual level of the expatriate manager, Minbaeva (2007) used "ability and willingness to transfer" as their dependent variable. 
Firms' transfer technology to create products and services to achieve business objectives, and human resource capability plays a critical role in the creation of a commercially viable product, service, or process (Whangthomkum, 2006). When considering technology transfer performance, firms should focus on performance outputs that indicate effectiveness instead of efficiency (Schroer et al., 1995). Hence, in order to measure technology transfer performance, this study focused more on product and process performance. The transfer of technology is expected to increase the company's technological capabilities. Hence, it will contribute to generate expected products that achieve the required quality level. In addition it will help in achieving the companies' production efficiency targets.

\section{Social Capital}

Social interaction is essential to assist in gaining tacit knowledge and personal experience on an individual. Social capital is a prominent concept that provides a foundation to describe and characterize the properties. It is the product of social interactions (Baron \& Markman, 2000). According to Putnam (2000), social capital is conceptualized as the network of associations, activities, or relations that bind people together as a community via certain norms and psychological capabilities, notably trust, which are essential for civil society and productive of future collective action or goods. This implies that the creation of social capital is influenced by social abilities, which is social competence (Rahmani \& Homayenikfar, 2010).

In a broader sense, social capital is not a one-dimensional concept (Putnam, 2000). Clarifying the dimensions of social capital is top priority because social capital has many complicated attributes related to the social context. It encompasses many aspects of a social context, such as social ties, trusting relations, and value systems that facilitate actions of individuals (Tsai \& Chashal, 1998). Researchers have differentiated between "internal" social capital that examines the "closure" or "bonding" which creates internal cohesiveness, and "external" social capital that examines "brokerage" or "bridging" linkages to external groups (Rahmani \& Mousavi, 2011). Nahapiet and Ghoshal (1998) proposed three dimensions of social capital which are structural, relational, and cognitive aspects. These three-dimensional frameworks have been employed to investigate the relationship between social capital and intra-organizational phenomena, such as creation of intellectual capital, inter-unit resource exchange, and organizational citizenship behavior.

The structural dimension of social capital describes the configuration of linkages between people within an organization; the relational dimension of social capital "describes the kind of personal relationships people have developed with each other through a history of interactions"; and the cognitive dimension refers to those "resources providing shared representations, interpretations, and systems of meaning" (Barney, 1991). Social capital is the factor that helps firms "get through the door", while the firm's social abilities determines the outcome of that interaction (Omar et al., 2011). Nahapiet and Ghoshal (1998) said that social capital facilitated the creation of new intellectual capital, which in turn led to the creation and exchange of new knowledge. The central idea of social capital is that a person's relationships, irrespective of their nature, may provide that person with resources that might be valuable to the firms (Xiong \& Bharadwaj, 2011).

In this paper, social capital is viewed as a phenomenon existing in all social relationships a person possesses, no matter if the connections are direct or indirect. The following definition encompasses this view and is used in this study to define social capital. Social capital is, "the sum of the actual and potential resources embedded within, available through and derived from the network of relationships possessed by an individual or social unit" (Xiong \& Bharadwaj, 2011). Thus, it is likely that the development of a network of strong social relationships will help to promote higher levels of experimental 
learning, since technological knowledge is possessed within the boundaries of the firm. Social capital also provides firms with an expanded number of learning opportunities, since these firms have a greater number of relationships from which to learn.

This study defines social capital as the combined resources embedded within, available through, and derived from the network of relationships possessed by an individual or organization (Nahapiet \& Ghoshal, 1998; Inkpen \& Tsang, 2005). Within this perspective, the central intention of social capital is network of relationships which is a valuable resource for the individual or organization. For successful transfer of tacit knowledge between network members, individual social capital must be developed, because the transfer normally requires intimate personal interactions. Considering the three dimensions of social capital introduced by Nahapiet and Ghoshal (1998), the hypotheses put forward in this study are as follows:

$\boldsymbol{H}_{1:}$ There is a positive relationship between structural aspects of social capital and technology transfer performance.

$\boldsymbol{H}_{2:}$ There is a positive relationship between relational aspects of social capital and technology transfer performance.

$\boldsymbol{H}_{3:}$ There is a positive relationship between cognitive aspects of social capital and technology transfer performance.

\section{Methodology}

\section{The Sample and Data}

Technology parks were developed to support industrial entrepreneurship, offer a conducive environment for the growth of high-technology industries and provide a crucial link among industry, the government, R\&D institutions, and universities. One of the purposes of technology park development is to catalyze the process of technology transfer. Hence, the survey of this study was conducted on a sample of industrial tenants operating in one of the technology parks in Malaysia. The unit of analysis chosen is the company whereby the data was collected using survey method from the target respondents at the managerial level. These people were chosen because they are close to the decision- making process involving the transfer of technology and they are involved in employee development. The sample size for this study was determined by using the table provided by Krejcie and Morgan (1970). The companies involved are from various fields of high technology industries, which include semiconductors, wafer fabrication, advanced electronics, biotechnology, chemical, industrial gases and services, mechanical electronics, medical and scientific instruments, microelectronics, and photo-electronics.

There are a total of 53 companies operating in the technology park. Therefore, a sample of 44 companies is needed in order to get result that reflects the target population with 95 percent of confidence level and confidence interval of 5 . By the use of simple random sampling procedure the questionnaires were distributed to the selected companies. However, only 19 completed questionnaires were received and give in 43 percent response rate. This response rate was quite reasonable compare to previous studies on the tenants of technology parks, for example 35 percent (21 companies out of 60 companies) in Vedovello (1997).

The data from the survey of this study can be analyzed with 95 percent confidence level and with a wider confidence interval that is 18. The respondents involved in this study are managers and directors or CEOs of the companies. In order to measure the level of technology transfer performance and social capital of the companies, the respondents were asked to indicate on seven point scale from 1 (low) to 7 (high). The data were analyzed using descriptive statistics explaining the respondents' background.

\section{Descriptive Analysis}

From the analysis 57.9 percent of respondents were less than five years in 
their designated positions, 26.3 percent have between five to ten years, and three respondents have more than five year experience. Table 1 shows the breakdown of this demographic and the size of the companies based on turnover.

Table 1: Number of Years of Experience in the Current Position and Size of the Companies

\begin{tabular}{|l|l|l|l|}
\hline Variables & Items & Frequency & Percentage \\
\hline Years of experience in the & Less than 5 years & 11 & 57.9 \\
\cline { 2 - 4 } current position & Between 5 to 10 years & 5 & 26.3 \\
\cline { 2 - 4 } & More than 10 years & 3 & 15.8 \\
\cline { 2 - 4 } & Total & 19 & 100.0 \\
\hline \multirow{3}{*}{$\begin{array}{l}\text { Turnover (RM millions per } \\
\text { year) }\end{array}$} & Less than 10 & 8 & 42.1 \\
\cline { 2 - 4 } & Between 31-100 & 6 & 31.6 \\
\cline { 2 - 4 } & Between 101-200 & 1 & 5.3 \\
\cline { 2 - 4 } & More than 200 & 4 & 21.1 \\
\cline { 2 - 4 } & Total & 19 & 100.0 \\
\hline
\end{tabular}

Table 2 shows the score of descriptive statistics of the variables. The mean score for the dimensions of social capital are from 4.694 to 5.189 , with a standard deviation ranging from 0.277 to 0.541 . The minimum and maximum score for all variables ranges from 4.167 to 5.611 , with the theoretical range of 1 to 7 .

Table 2: Descriptive Statistic of Variables

\begin{tabular}{|l|l|l|l|l|}
\hline Variables & Minimum & Maximum & Mean & Std. Deviation \\
\hline Structural social capital & 4.778 & 5.611 & 5.103 & 0.338 \\
\hline Cognitive social capital & 4.167 & 5.333 & 4.694 & 0.541 \\
\hline Relational social capital & 4.889 & 5.556 & 5.189 & 0.277 \\
\hline Technology transfer performance & 4.833 & 5.167 & 4.972 & 0.577 \\
\hline
\end{tabular}

\section{Reliability Analysis}

In order to evaluate the reliability of measurement scales an internal consistency analysis was performed separately for the items of technology transfer performance and each dimension of social capital by using the SPSS reliability procedure. An adequate alpha value of greater than 0.6 , while alpha values of between 0.7 and 0.9 can be considered optimal (Streiner \& Norman, 2003). As shown in Table 3, the alpha values of reliability analysis for this study ranges from 0.756 to 0.969 . Thus, it can be concluded that this instrument is reliable as it has internal consistency and is therefore reliable.

Table 3: Reliability Analysis Result

\begin{tabular}{|l|l|l|l|}
\hline Variables & Number of items & Mean & Alpha \\
\hline Structural social capital & 7 & 5.103 & 0.897 \\
\hline Cognitive social capital & 4 & 4.694 & 0.756 \\
\hline Relational social capital & 5 & 5.189 & 0.889 \\
\hline Technology transfer performance & 4 & 4.972 & 0.969 \\
\hline
\end{tabular}




\section{Results and Discussion}

\section{Hypothesis Testing}

With the purpose of understanding the nature of the association between technology transfer performance and social capital, a statistical test (bivariate correlation) was used. The correlations between technology transfer performance and the three dimensions of social capital are shown in Table 4.

Table 4: Pearson Correlation Coefficients of Social Capital with Technology Transfer Performance

\begin{tabular}{|l|l|l|}
\hline Variables & $\begin{array}{l}\text { Technology } \\
\text { performance }\end{array} \quad$ Transfer & Sig. (1-tailed) \\
\hline Structural social capital & $.711^{* *}$ & 0.001 \\
\hline Cognitive social capital & $.439^{*}$ & 0.069 \\
\hline Relational social capital & $.495^{*}$ & 0.037 \\
\hline
\end{tabular}

**. Correlation is significant at the 0.01 level (1-tailed).

*. Correlation is significant at the 0.05 level (1-tailed).

The result shows that the three dimension of social capital are significantly correlated with technology transfer performance. There is strong positive relationship between technology transfer performance and structural social capital, with a Pearson correlation coefficient of 0.711 being significant at 0.01 levels, which gives $\mathrm{r}^{2}$ equal to 0.51 . This indicates that if there is structural social capital increases, the performance of technology transfer also will increase with $50.1 \%$ of the variance being explained by the structural social capital. As claimed by previous researchers (examples Lane \& Lubatkin, 1998; YliRenko, Autio, \& Sapienza, 2000; Zahra, Ireland, \& Hitt, 2000), knowledge transfer is facilitated by intensive social interactions of organizational actors. With the positive atmosphere, it is expected that this will support the flow of knowledge between the intra and inter-department.

Another social capital dimension that has a significant relationship with technology transfer performance is the relational aspect. There is a moderate relationship with a correlation coefficient of 0.495 at the 0.05 significance level, which gives and $r^{2}$ equal to 0.25 . The findings indicate there is a certain extent of relational influences on the technology transfer performance. Ghoshal and Bartlett (1994) argued that the creation of a supportive organizational context would result a positive impact namely induce actions in its members in furthering the interests and the welfare of the organization as an end in itself, not just a mean to their personal end-cognitive dimension. In addition, it enhances the diffusion of information and mutual cooperation and finally, would engender individual-level behaviors that facilitate the development of trust among organizational members -relational dimension.

With respect to the third dimension, the finding results show that the cognitive social capital is also significantly correlated to technology transfer performance. The results provide evidence to show the link between social capital and the technology transfer performance. Hence, to create a supportive organizational context that is able to enhance associability, companies should establish some managerial practices such as clear standards of behavior create a shared purpose and develop a collective identity or creating a meaningful relationship at work. From the results it can be summarized that Hypothesis $1\left(\mathrm{H}_{1}\right)$, Hypothesis $2\left(\mathrm{H}_{2}\right)$ and Hypothesis $3\left(\mathrm{H}_{3}\right)$ are supported.

\section{Conclusion}

Structural social capital is built through horizontal organizations and networks that have collective and transparent decision making processes, leaders' accountability, and practices of collective action and mutual responsibility. The findings suggest 
that structural social capital plays a significantly positive role for the success of technology transfer. This indicated that the composition and practices of local level institutions, both formal and informal are important in ensuring the success of technology transfer. Cognitive social capital is the less tangible side of social capital that refers to values, beliefs, attitudes, behavior and social norms. The findings suggest that cognitive social capital also has a positive relationship with technology transfer performance. As well, it was found that relational social capital also has relationship on the performance of technology transfer. This explains that personal relationships developed between individuals through a history of interactions also contribute to the success of technology transfer. Based on these findings, it can be concluded that there are significant relationships between technology transfer performance and social capital of the companies in the technology park studied. However, this study was conducted on one of technology parks in Malaysia. Hence, the results are constrained by this method and generalization may be difficult to be made. It is therefore desirable to extend the study to examine the influence of social capital on technology transfer performance in other technology parks in the country, and eventually in other countries.

\section{References}

Ambos, B. \& Schlegelmilch, B. B. (2008). "Innovation in Multinational Firms: Does Cultural Fit Enhance Performance," Management International Review, Vol. 48, No. 2, pp. 189-206.

Battisti, G. \& Stoneman, P. (2005). "The Intra-Firm Diffusion of New Process Technologies," International Journal of Industrial Organisation, Vol. 23, No. 2005, Pp. 1-22.

Cho, K. R. \& Lee, J. (2004). "Firm Characteristics and MNC's Intra-Network Knowledge Sharing," Management International Review, Vol. 44, No. 4, Pp. 435-455.
Choi, H. J. (2009). "Technology Transfer Issues and a New Technology Transfer Model," The Journal of Technology Studies., Vol. 35, No. 1.

Davenport, T. H. \& Prusak, L. (2000). Working Knowledge: How Organizations Manage What They Know, Boston Harvard Business School Press.

Foss, N. J. \& Pederson, T. (2002). "Transferring Technology in Mncs: The Role of Sources of Subsidiary Technology and Organisational Context," Journal of International Management, Vol. 8, No. 1, Pp. 49-67.

Ghoshal, S, \& Bartlett, C. A. (1994). "Linking Organizational Context and Managerial Action: The Dimensions of Quality of Management," Strategic Management Journal, 15: Pp. 91-112, 1994.

Gupta, A. K. \& Govindarajan, V. (2000). "Knowledge Flows within Multinational Corporations," Strategic Management Journal, Vol. 21, Pp. 473-496.

Hippel, E. V. (1994). "Sticky Information" and the Locus of Problem Solving: Implications for Innovation," Management Science, Vol. 40, Pp. 429-439.

Jansen, J. J. P. et al., (2005). "Managing Potential and Realised Absorptive Capacity: How Do Organisational Antecedents Matters?," Academy of Management Journal, Vol. 48, No. 6, Pp. 999-1015.

Jian, P. \& Li-Hua, R. (2006). 'The Appropriateness and Effectiveness of Tacit Knowledge Transfer in E-Business Companies: Empirical Evidence From China,'

Kedia, B. L. \& Bhagat, R. S. (1988). "Cultural Constraints on Transfer of Technology across Nations: Implications for Research in International and Comparative Management," Academy of Management Review, Vol. 13, No. 4, Pp. 559-571. 
Lane, P. J, et al., (2006). "The Reification of Absorptive Capacity: A Critical Review and Rejuvenation of the Construct," Academy of Management Review, Vol. 31, Pp. 833-863.

Lane, P. J. \& Lubatkin, M. (1998). "Relative Absorptive Capacity and Inter Organizational Learning," Strategic Management Journal, Vol. 19, Pp. 461-477.

Lee, M. T. et al. (2011). "Soft Technology Transfer for Japanese MNCs in Malaysia a Conceptual Model," Presented at the the International Longlife Learning Conference.

Li-Hua, R. \& Khalil, T. M. (2006). "Technology Management in China: A Global Perspective and Challenging Issues," Journal of Technology Management in China, Vol. 1, No. 1, Pp. 9-26.

Li-Hua, R. (2006). "Examining the Appropriateness and Effectiveness of Technology Transfer in China," Journal of Technology Management in China, Vol. 1, No. 2, 2006, Pp. 208-223.

Li, L. (2005). "The Effects of Trust and Shared Vision on Inward Knowledge Transfer in Subsidiaries' Intra-and InterOrganisational Relationships," International Business Review, Vol. 14, No. 1, Pp. 77-95.

Lin, B. W. \& Berg, D. (2001). "Effects of Cultural Difference on Technology Transfer Projects: An Empirical Study of Taiwanese Manufacturing Companies," International Journal of Project Management, Vol. 19, Pp. 287-293.

Minbaeva, D. B. (2007). "Knowledge Transfer in Multinational Corporations," Management International Review, Vol. 47, No. 4, Pp. 567-593.

Mitelman, J. H. \& Pasha, M. K. (1997). Out From Underdevelopment Revisited: Changing Global Structures and the Remaking of the Third World, New York: St. Martin's Press.
Omar, R. et al. (2011). "The Concept of Absorptive Capacity in Technology Transfer (TT) Projects," In International Conference on Intelligent Bilding and Management, Singapore, Pp. 328-334.

Rahmani, Z. \& Mousavi, S. A. (2011). Enhancing the Innovation Outcomes of Absorptive Capacity in the Organization: A Conceptual Framework. International Journal of Innovation.

Riusala, K. \& Smale, A. (2007). "Predicting Stickiness Factors in the International Transfer of Knowledge through Expatriates," International Studies of Management \& Organisation, Vol. 37, No. 3, Pp. 16-43.

Rose, R. C. et al., (2009). "A Review on the Effects of Inter-Firm Technology Transfer Characteristics and Degree of Technology Transfer," European Journal of Social Sciences, Vol. 8, No. 2, Pp. 297-309.

Sarif, S. M. \& Ismail, Y. (2006). 'The Search for Indigenous Technology within Malaysian Economic Policies,' Journal of Technology Management and Entrepreneurship, Vol. 5, No. 2, Pp. 71-87.

Sarina, M. N. (2010). "The Moderating Effect of Organizational Structure and Quality Practices on Absorptive Capacity, Technology Compatibility and Technology Transfer Relationship," Doctor of Philosophy, Centre for Graduate Studies, College of Business, University Utara Malaysia, Sintok.

Streiner, D. L. \& Norman, G. R. (2003). Health Measurement Scales: A Practical Guide to Their Development and Use (3rd Ed.). Oxford, UK: Oxford University Press.

Szulanski, G. et al. (2004). "When and How Trustworthiness Matters: Knowledge Transfer and the Moderating Effect of Causal Ambiguity," Organisation Science, Vol. 15, No. 5, Pp. 600-613. 
Vedovello, C. (1997). "Science Parks and University-Industry Interaction: Geographical Proximity between the Agents as A Driving Force," Technovation, Vol. 17, No. 9, Pp. 491-502.

Xiong, G. \& Bharadwaj, S. (2011). "Social Capital of Young Technology Firms and Their IPO Values: The Complementary Role of Absorptive Capacity," Journal of Marketing.

Yli-Renko, H., Autio, E. \& Sapienza, H. J. (2001). "Social Capital, Knowledge Acquisition, and Knowledge Exploitation in Young Technology-Based Firms," Strategic Management Journal, 22: 587-613.

Zahra, S. A., Ireland, R. D. \& Hitt, M. A. (2000). "International Expansion by New Venture Firms: International Diversity, Mode of Market Entry, Technological Learning, and Performance," Academy of Management Journal, 43: 925-950. 